\title{
MEMÓRIAS DA DIVERSIDADE NA PARAÍBA: AS DORES E OS GUARDINS DE NINA KELLY
}

Sérgio Pessoa Ferro ${ }^{1}$

Resumo: Este trabalho conta a história de vida de Nina Kelly, sessenta anos, travesti, transformista, costureira, destaque de escola de samba. Nascida no interior da Paraíba, migrou para a capital ainda adolescente, onde se estabeleceu. A narrativa foi construída com base numa metodologia interdisciplinar, elegendo o gênero textual da entrevista comentada como método de produção discursiva. Posicionamos os estudos sobre direitos humanos entre a teoria literária, história, geografia, psicologia e direito. Como fontes primárias de informação, manejamos, além da entrevista semiestruturada, fotografias decorrentesdo acervo pessoal da sujeita. A perspectiva de Maurice Halbwachs nos oferece o conceito de memória enquanto construção social, de modo que o individual e o coletivo se cruzam em nossas lembranças. Assim, através das reminiscências de Nina, pretendemos mergulhar na memória social da comunidade sexo-gênero dissidente em João Pessoa.

Palavras-chave: diversidade sexual e identidades de gênero; memória social; direitos humanos; Paraíba.

\begin{abstract}
This paperis about a life history of Nina Kelly, fifty-nine years old, transvestite, transforming, seamstress, highlight of samba school. Born in the country of Paraíba, it migrated to the capitalstill adolescent, where it is seen. The narrative was constructed based on an interdisciplinary methodology, choosing the textual genre of the interview as a method of discursive production. Students position
\end{abstract}

\footnotetext{
${ }^{1}$ Doutorando na área de Direitos Humanos e Desenvolvimento pelo Programa de Pós-Graduação em Ciências Jurídicas, Mestre pelo Programa de Pós-Graduação em Ciências Jurídicas (2017) e pelo Programa de Pós-Graduação em Direitos Humanos, Cidadania e Políticas Públicas (2019), ambos da Universidade Federal da Paraíba. Graduado em Direito pela Universidade do Estado da Bahia (2013). Advogado, credenciado sob a inscrição n. 42.536 OAB/BA. Realizador audiovisual. Pesquisa na área de Direitos Humanos, Epistemologia, História do Direito, Direito de Crianças e Adolescentes, Direito da Igualdade Racial, Direito da Diversidade Sexual. Integra os grupos de pesquisa História do Direito (PPGCJ/UFPB) e Socioeducação em análise (PPGDH/UFPB). Atualmente, trabalha com consultoria jurídica junto ao Centro de Referência em Direitos Humanos, da Universidade Federal do Rio Grande do Norte
} 
on human rights between literary history, history, geography, psychology and law. As the primary sources of information, they manage, in addition to the semistructured interview, photographs of the personal collection of the publication. The perspective of Maurice Halbwachs offers us the concept of memory as a social construction, so that the individual and the collective are crossed in ample memories. Thus, through the reminiscences of Nina, we intend to gather in the social memory of the dissenting sex-gender community from João Pessoa.

Keywords: sexual diversity and gender identities; social memory; human rights; Paraíba.

\section{Introdução}

Os indicadores marcam um crescimento nos assassinatos motivados por ódio a pessoas que expressam sexualidades e identidades de gênero divergentes do padrão cisheteronormativo. O Relatório 2017 de pessoas LGBT mortas no Brasil, elaborado pelo Grupo Gay da Bahia, registrou 445 mortes, sendo 387 assassinatos e 58 suicídios, nunca antes a organização computou tantos óbitos em quatro décadas de levantamento.

A Anistia Internacional, em seu portal online, publicou declaração do Grupo Transrevolução, do Rio de Janeiro, afirmando que a expectativa de vida de uma pessoa trans em nosso país corresponde a cerca de 30 anos, muito inferior à média nacional de 75, 2 anos, segundo o Instituto Brasileiro de Geografia e Estatística (Queiroz, 2017). A violência letal, a transfobia institucional, o trabalho no mercado informal de prostituição, e muitos outros fatores, engendram um panorama de genocídio da população trans.

A história se escreve coletivamente, o direito à memória é uma pauta insistente da luta por direitos humanos na América Latina, em busca de recontar nosso passado de colônia, escravidão e ditaduras civil-militares. Lésbicas, travestis, transexuais, bissexuais, bichas e as mais variadas expressões dissidentes na sexualidade e identidade de gênero: se não reproduzimos, como existem tantas?

A perguntalançada no parágrafo anterior ironiza a noção biológica do gênero e da sexualidade, induzindo sobre a presença histórica de nossas 
subjetividades sexo-gênero dissidentes. A sátira do uso reprodutivo da (hetero)sexualidade, pautada na divisão binária dos papéis de gênero, remete à reprodução cultural de nossos modos de vida, indispensável ao fortalecimento de nossa comunidade e à sensação de pertencimento à sociedade que, apesar de toda violência, também ajudamos a construir.

Fundimos o debate de gênero e sexualidade com os atravessamentos entre memória, história e esquecimento. A memória deslocada, apreendida pela matriz cis-heteronormativa de nossa cultura, não guarda as lembranças de nossas resistências. Sem passado, as gerações que cresceram na fase de conquista de direitos podem se esquecer das lutas dos movimentos sociais pela diversidade, caindo na ilusão mercantil do reconhecimento das identidades divergentes, ou converter-se à ameaça conservadora.

Assim, este trabalho se dedica à narrativa da história de vida de Nina Kelly, travesti paraibana, nascida em 05 de junho de 1959, em Serraria, no interior do estado, numa família de agricultores, migrando para a capital mediante intervenção do proprietário da fazenda em que a irmã trabalhava.
Transformista desde os anos 1980, hoje é costureira, estilista e administra um brechó. Há 30 anos, desfila nas escolas de samba do carnaval tradição de João Pessoa. Em meio às reminiscências de Nina, velejaremos pelos mares das memórias coletivas da população LGBT na Paraíba.

Este texto decorre de dissertação de mestrado defendida na linha de pesquisa sobre territórios, direitos humanos e diversidades socioculturais, junto ao Programa de Pós-Graduação em Direitos Humanos, Cidadania e Políticas Públicas da Universidade Federal da Paraíba; em agosto de 2018, entrevistei Nina Kelly, pensandoseu discursona constituição de uma memória social da comunidade sexo-gênero dissidente. Por meio de uma abordagem metodológica interdisciplinar do discurso memorialístico autobiográfico, comentaremos as memórias de Nina em sua vivência da subjetividade travesti.

Se "as memórias equivalem ao descortino de uma imensa e plana paisagem cujo horizonte se estende para trás, estabelece-se no presente e se abre para adiante" (Lima, 2013:369), nos tópicos seguintes, passearemos pela paisagem de recordações exposta por 
Nina em seu discurso enunciado na perspectiva da velhice trans, sem almejar um ordenamento biográfico literal ou sujeitá-la a uma rigorosa aferição historiográfica.

Nos procedimentos de análise, partiremos dos enunciados elaborados pela sujeita na estilização de suas memórias, em diálogo com as teorias de Berenice Bento (2008), Sônia Khède (1982), Jota Mombaça (2017), Trevisan (2000), Judith Butler (2016), entre outras autoras que orientaram a pesquisa e com os marcadores que estruturaram o roteiro de entrevista. Ao invés de montar um tribunal científico com competência para julgar o real e o ficcional, tomaremos as palavras construídas pelas lembranças da interlocutora como ponto de partida, abordando as tramas, personagens, cenários, temas e histórias a que sua voz dá existência.

$\mathrm{Na}$ escrita das reminiscências sexo-gênero dissidentes paraibanas, tomamos a entrevista comentada como gênero textual (Vanoye, 1985), transcrevendo a narrativa oral contada por Nina Kelly - mais que uma informante, protagonista da narrativa. Homossexual, me conecto com Nina pela sexualidade e pela raça. Nosso fenótipo que apresenta traços indígenas faz com que ela me veja como um semelhante, ou, de forma mais apropriada, um parente. Não à toa, durante o campo de pesquisa, ela me apresentava às pessoas como seu sobrinho. $\mathrm{O}$ gênero e a classe social nos distanciam, de modo que será a ponte dos direitos humanos que firmará as alianças.

\section{Personagens que embaralham o real e o fictício}

Eu sou a madrinha deles. Eu dou respeito a eles, e eles me consideram. Uma vez foi com Fernanda, que eu defendi. Outra vez foi com Delícia. Os caras iam pegar Delícia, cheguei na hora e eles não mexeram. Delícia mexendo com os caras, acho que não gostaram. Eles voaram em cima dele, só que eu estava perto e não deixei. Eles me consideravam, me respeitaram. Até me chamaram atenção:

- Como é que você é uma fêmea e fica perto de uns viados safados desses. Até isso disseram comigo. Eu dizia:

- Não, pode ser o que for, mas ele é gente. Ele é cristão, ele é humano. A gente não pode se desfazer de nenhuma pessoa.

Foi quando eles viram que eu estava certa. Ele saiu, não mexeram mais com Delícia, nem comigo. Foi em Mandacaru, no dia do desfile da escola de samba. A escola estava perto da Ponte Preta. “- Aqui vocês não vão bater, não". Eu dei conselho. Eu comecei a explicar que eles não podiam fazer isso, que Delícia era humano. Comecei a explicar que eles não eram pais de Delícia. Ele pegou e disse, "— sua felicidade é ela. Como é que a senhora dá atenção 
a um viado safado desse?" Até me chamavam de senhora, pensando que eu era uma fêmea. Delícia ficou feliz:

- Nina desse jeito, o povo pensa que ela é uma mulher de verdade. Pensa que é uma fêmea.

Ela me agradeceu:

- Nina, vale a pena a pessoa ser sua amiga. Você protege as pessoas mesmo. Você é desse jeito, mas não tem quem diga. Eu dou meu respeito. (Nina Kelly)

A narradora nos coloca no bairro do Mandacaru, periferia da capital da Paraíba, durante o desfile de escolas de samba. No carnaval, a rua torna-se seu domínio. Lendo as palavras com as quais registra suas memórias autobiográficas, ainda que atravessadas por mim pela transcrição, nos deparamos com as fronteiras entre ficção e história, ao passo que seu trabalho de expressão da subjetividade expõe a transparência frágil do sexo-verdadeiro. Convidamos Sônia Salomão Khède a somar no debate sobre memorialismo e identidade:

Mas o memorialismo, embora não seja exclusivo da atividade artística, ficcional, é o produto de base do processo poiético, podendo se apresentar como a lembrança edificadora de mitos pessoais e monumentos de autorreconhecimento ou como lembrança operadora da diferença em que a lembrança é ato de descoberta. (Khède, 1982: 191).
Em sua produção de memórias, Nina compartilha conosco seu conceito de identidade de gênero na medida em que o edifica como monumento da linguagem. $\mathrm{Na}$ ocasião discursiva, a interlocutora relata sua posição na comunidade sexo-gênero dissidente: é considerada "madrinha deles", marcando uma diferença entre ela e eles - nós, os homossexuais masculinos cisgêneros, ainda que afeminados. Neste grupo, ela encaixa as personagens "Fernanda" e "Delícia".

Como nada em Nina é linear, senão ela nos enuncia um universo repleto de surpresas e contrações, tais personagens recebem nomes femininos, embora nos sejam enunciados como "viados" em oposição a sua condição de "fêmea", que aparenta ser uma "mulher de verdade". A respeito desse jogo de paródias, em sua obra $O$ que é transexualidade, Berenice Bento, comenta: 
sentimento é mais ou menos feminino/masculino? As/os mulheres/homens biológicos em suas ações cotidianas também interpretam o que é mulher/homem "de verdade", isto porque a verdade dos gêneros não está no corpo, já nos diz a experiência transexual, mas nas possibilidades múltiplas de construir novos significados para os gêneros. (Bento, 2008: 47).

A rigidez binária do lugar de mulher, que configura seu local de fala, joga com o atrevimento de sua própria narrativa, ao se descolar da funçãopersonagem e se pôr na função-autora: "até me chamavam de senhora, pensando que eu era uma fêmea", como se risse da situação cênica com uma voz que mescla deboche e orgulho. Em outro contexto, ela propõe um enunciado semelhante: "sou travesti, você agora vai se lascar comigo", relembrando uma cena em que escapara de um assalto. E complementa: "Ele nem descobriu que eu não era moça", explicitando que não se identifica com a condição de mulher cisgênero expressa pela designação "moça".

Hélio Silva, em sua obra Travesti: a invenção do feminino (1993), publicou uma densa etnografia carioca com sujeitas acerca de suas travestilidades, encontrando no espaço urbano os cuidados para a enunciação da travesti brasileira dentro das

\section{6}

configurações teóricas do gênero, pelo que realça em sua identificação justamente o amálgama masculinofeminino, o não-lugar da mulher de pau: "Transvestire, transexual. A condição não seria exatamente a não-condição? Seu lugar não seria a transgressão?" (Silva, 1993: 92).

Outro ponto relevante no excerto em análise é o argumento invocado pela protagonista para agir em defesa de Delícia, que enunciado como "viado" performa um gênero não-inteligível à heteronorma, logo, destituído de humanidade. Ela argumenta: "pode ser o que for, mas ele é gente. Ele é cristão, ele é humano. A gente não pode se desfazer de nenhuma pessoa". Nina articula o discurso religioso cristão que universaliza a condição de pessoa humana para revestir a personagem de humanidade, afastando-lhe a abjeção que autoriza a violência (Butler, 2016).

\section{Alegorias transformistas no carnaval paraibano}

Pronto, através da casa de dona Nanhãcomecei a brincar o carnaval. Eu estava com dezenove anos e ia fazer vinte. Na Noel Rosa. Faz tempo. Depois da Noel Rosa, veio a Malandros do Morro. Depois da Malandros do Morro, veio a Independentes de 
Mandacaru. Depois da Independentes de Mandacaru, veio a Catedráticos. Depois da Catedráticos, veio a Unidos do Roger. Depois da Unidos do Roger, brinquei também na Império do Samba. Depois da Império do Samba, brinquei em uma que já faz tempo que se acabou... "não sei o quê flor". Sei que tem mais duas escolas que já se acabaram. [...]

Todo ano, quando dá tempo, eu desfilo e entro para as escolas de samba. E levo componente para desfilar também. Faz tempo que eu danço, bem novinha. Já faz mais de trinta anos de carnaval.

Comecei a brincar em carro alegórico depois que comecei a aumentar as fantasias. O povo, “ah, sua fantasia já dá para sair numa alegoria". Comecei a brincar em cima das alegorias. De me apresentar bem, me sentir à vontade, bem recebida. As alegorias, meu gosto é que sejam bem bonitas, destacando a fantasia. (Nina Kelly).

A narrativa autobiográfica deflagrou-se a partir do roteiro de entrevista elaborado com base na história oral de vida temática (Meihy, 1996) focando neste aspecto da personalidade da entrevistada: seus trinta anos de carnaval tradição nas escolas de samba de João Pessoa. No percurso, transitamos pelos labirintos da memória da interlocutora que partilhou conosco lembranças individuais com a espessura tão larga que nos fez reconhecê-las enquanto vivências de grupo (Halbwachs, 1990) da comunidade sexo- gênero dissidente, em especial, das travestis.

Rememorando sua passagem pelas avenidas, Nina nos desenha um diagrama histórico das escolas de samba que orientam os festejos carnavalescos tradicionais da cidade. Sua história confunde-se com a do carnaval, ao menos em seus acontecimentos nas últimas três décadas. A enunciação carnavalesca da protagonista nos cria uma atmosfera mágica, repleta de fantasias, alegorias e ritmos, onde tudo parece possível. A metamorfose constitui a regra da beleza. Nesse tempo propício à brincadeira, sua subjetividade está "à vontade, bem recebida".

No artigo Memória, antropofagia e carnaval, Francisco Lopes Junior (1988), analisando poemas de Silvano Santiago, pensa as matizes do folclore carnavalesco no cerne da cultura brasileira, permeada pelo seu caráter dramático oscilante entre a tradição judaico-cristã ocidental e uma exaltação dionisíaca manifestada de modo explícito no carnaval, uma festa contrária à repressão e liberalizante:

O racional será obrigado a travestir-se com muitas máscaras, terá de participar necessariamente da festa para se desmascarar enquanto linha única de 
Periódico do Núcleo de Estudos e Pesquisas sobre Gênero e Direito

Centro de Ciências Jurídicas - Universidade Federal da Paraíba

V. 8 - No 03 - Ano 2019

ISSN | 2179-7137 | http://periodicos.ufpb.br/ojs2/index.php/ged/index

pensamento. É o exercício de uma prática carnavalizante para destruição do lado acadêmico, doutor, para o qual nos chamavam a atenção os manifestos visionários de Oswald de Andrade. Cada recorte do real sempre é uma problematização, porque o reagrupamento é interpretativo através de recursos técnicoformais de desmascaramento, transformações, deformações, adaptações, apropriações. Todos esses elementos nos permitem verificar a re-invenção de processos carnavalescos que, partindo de uma apresentação, revelam-se excelentes índices de mudança e transformação. (Lopes Junior, 1988:280).

A subjetividade-travesti da protagonista está em paz porque neste festejo sua poesia pode ser escrita e recitada em voz alta no palco da rua, nas formas refinadas de suas fantasias, que engolem os códigos cisheteronormativos de gênero e vomitam reinventando a estética do corpo. Nunca a incorporação das marcas do feminino pode ser vivenciada com tanta liberdade, transgredindo a ilusão televisionada hegemonicamente pelo padrão branco de feminilidade na elegância de ser quem se quer: "já faço o rabo de cavalo bem chique, saindo aqui detrás. Preso, aí vem. Que nem Xuxa fez".

Figura 1: Olha a Noel Rosa como faz tempo, bem diferente, eu um batuqueiro.

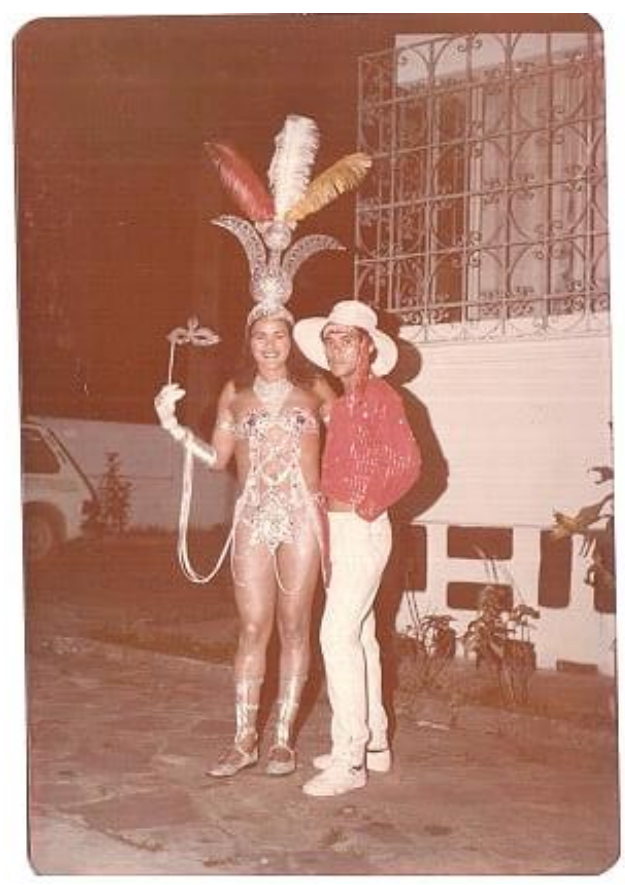

Fonte: acervo pessoal

Olha, como era. Eu bem novinha. O cara, "- deixa eu bater uma foto com você, deixa eu bater uma foto com você" "- E eu". Ainda me lembro, ele disse "— vem pra cá, para não perder meu visual com ela. Aí botou a menina em cima dele, para ficar mais perto de mim. Mas faz tempo. Bem bonitinho esse rapaz. (Nina Kelly). 
Em seu livro intitulado Testemunha ocular: o uso de imagens como evidência histórica, Peter Burke (2017), estuda a dimensão iconográfica das fotografias e retratos, destacando elementos como a identidade dos fotografados e fotógrafos, a cumplicidade entre ambos, a composição das cenas, os aspectos da vida real retratados, a forma simbólica, os gestos e vestimentas:

Sejam eles pintados ou fotografados, os retratos registram não tanto a realidade social, mas ilusões sociais, não a vida comum, mas performances especiais. Porém, exatamente por essa razão, eles fornecem evidência inestimável a qualquer um que se interesse pela história de esperanças, valores e mentalidades sempre em mutação. (Burke, 2017: 44)

A tecnologia empregada nas fotografias de Nina ainda não era digital, à época, as imagens eram capturadas no suporte do filme fotográfico, trazendo uma carga estrutural da câmera enquanto bem de consumo na sociedade do capital. A aquisição desse equipamento indicava o pertencimento a uma classe social.

A figura 1 nos apresenta Nina jovem ao lado de um batuqueiro da escola de samba Noel Rosa. A fotografia em tom sépia dá indícios da passagem do tempo. Com uma fantasia bem elaborada em brilhos, luvas, máscara e um acessório de cabeça deslumbrante ornado com penas, Nina expõe seu talento para a produção de figurinos e encena o papel mitológico da travesti no carnaval, desafiando o público da avenida a compartilhar sua grande dignidade.

Recebi o honroso convite para desfilar na escola de samba Unidos do Roger, presidida por Fernanda Benvenutty, no carnaval tradição João Pessoa 2018, quando pude colocar meu corpo na rua e sentir um pouco das emoções de nossa protagonista em seus muitos carnavais. Fomos a ensaios, provas de figurino e, no dia do desfile, gravamos tudo em audiovisual. Vestido com um traje amarelo por baixo, uma armação com setas apontadas para cima, braceletes e um acessório de cabeça cilíndrico, tudo no degrade do arco-íris, compus a Ala da Diversidade da agremiação, somando-me a dezenas de pessoas sexo-gênero dissidentes que militam na arena da diversidade no cenário paraibano. Parecia um sonho.

No carnaval, a travestilidade torna-se real, ao invés de utópica: 
A escola de Fernanda é a que tem mais travestis, masculino não tem muito. Tem mais travesti, sapatona. Por isso que todo ano ela ganha, porque sabe que as travestis botam pra foder mesmo. (Nina Kelly).

O sonho de um mundo em que "travestis e sapatonas" são maioria constitui a quimera realizável nos festejos carnavalescos pelo discurso memorialístico da protagonista. A clausura moral sobre os corpos sexogênero dissidentes em nossa cultura remonta à proibição do pecado da sodomia que condenava os culpados ao Tribunal do Santo Ofício no Brasil Colônia (Vainfas, 1989). A tentativa neurótica de esconder tal vivência nos discursos oficiais da história brasileira desmascara-se no carnaval, como resgata João Silvério Trevisan, em suas reminiscências da cena travestida:

Na vida brasileira, parece que essa modalidade de travestismo teatralizado evoluiu por duas vertentes diversas. Uma meramente lúdica - floresceu, de modo esfusiante, no carnaval, com centenas de pais-de-família (ou não) vestidos com as roupas de suas esposas (ou irmãs ou mães ou amigas), durante três dias ao ano. A outra vertente voltou-se para um objetivo mais profissional, com o surgimento, nos palcos, do atortransformista que vive profissionalmente da imitação de mulheres e, com frequiência, é
50

travesti também na vida cotidiana. (Trevisan, 2000: 145).

Tão valiosa quanto a atuação militante na política institucional se mostram as ações de Nina Kelly nas artes transformistas, elaborando artifícios culturais que fundam uma comunidade sexo-gênero dissidente paraibana:

As décadas de 1960, 1970 e parte da de 1980 viveram a eclosão dos shows de travestis brasileiras com inúmeros espetáculos. É no processo de formação da comunidade LGBT brasileira, que os espetáculos com artistas transformistas deixam de ser meras paródias do sexo oposto e se tornarem um novo estilo de performance. A arte transformista passou a estar associada a uma concepção de um travestismo profissional, inclusive com a existência de uma regulamentação da profissão de ator-transformista (Trevisan, 1986/2000). A arte transformista, quando inserida no âmbito da produção cultural LGBT, passou de maneira antropofágica a mesclar de forma complexa o transformismo moderno e travestismo cênico junto atravestilidade e outras vivências da sexualidade e do gênero. Não se tratava mais somente da capacidade de impersonificar identidades diferentes ao gênero atribuído ao nascimento, mas de colocar o próprio gênero e a sexualidade como elemento de debate a partir dos elementos culturais da comunidade LGBT, produzindo a ativação subversiva de elementos de gênero e sexualidade hegemônicos e subalternos por meio da paródia, do glamour, da fantasia ou da caricatura. $\mathrm{O}$ transformismo tornava-se o 
criativo celeiro da comunidade LGBT e todo seu disparate. (Bortolozzi, 2015: 131).

A imitação do gênero está autorizada pelo devir carnavalesco, um pulo livre para a arte transformista, que engorda nesse período para continuar seu brilho nos dias áridos e agressivos do restante do ano. Para a protagonista, a arte transformista consagrou-lhe a composição de seu nome social:

Nina foi do capitão Eliezer e o Kelly foi... Qual show que eu fiz? Foi a menina que disse, "—- ó, Nina, não bota Nina não, chama Nina Kelly". "Agora, com vocês, Nina Kelly". Qual foi o show que eu fui fazer? Parece que foi na praia, na Parada Gay, que teve a gravação das travestis. Não, foi no Drag Mel, que o rapaz que chamava, Luciano fazia parte do que chamava as pessoas. Ele me botou. Foi Luciano e Chiclete, que disse, "não chama, Nina, não. Na hora do chamado. Dê outro nome". Luciano disse, "— - já sei qual é que vou mandar o rapaz chamar: com vocês, Nina Kelly, do Castelo
Branco". Quando falou Nina Kelly, o povo ficou doido para saber quem era. Quando viram que era eu, pronto. Foi mais no miss simpatia. Todo mundo no teatro Santa Roza, era até em cima nos camarotes. Danaram o pau a gritar, “- eita, é Nina. Já ganhou, já ganhou”. Eu disse, “- oxente”. Aí veio o show, depois teve de maiô. Tiveram várias roupas. $\mathrm{O}$ meu ficou bonito. (Nina Kelly).

Esta é a sequência da cena de nomeação relatada pela interlocutora. Anos depois do batismo do prenome Nina pelo Capitão Eliezer, durante um concurso de shows transformistas chamado Drag Mel, organizado pelo Movimento do Espírito Lilás, uma de suas saudosas lideranças, Luciano Bezerra, complementa o gesto do passado designando-lhe o Kelly, à moda da atriz de norte-americana Grace Kelly. Nina da televisão, Kelly do cinema, uma história de transgressão do real.

Figura 2: Nina Kelly e Luciano Bezerra

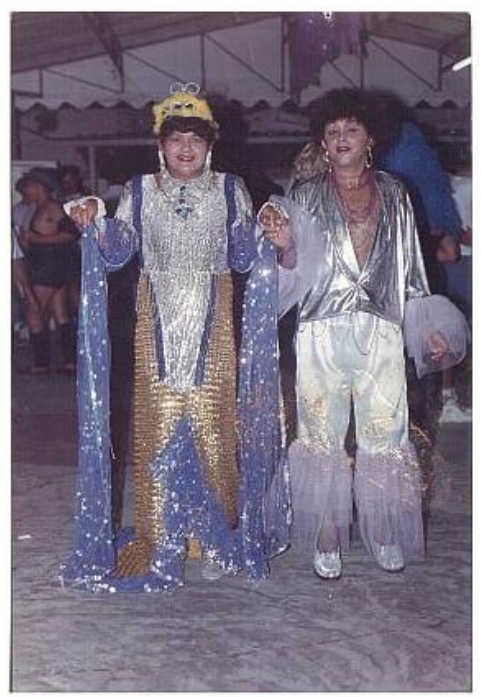


Fonte: acervo pessoal

Parece que tenho até uma foto guardada. Faz tempo, mas eu tenho. A lembrança, desse Drag Mel. Foi muito lindo.Minha intimidade era mais com Luciano. Ele entrou até no carnaval, porque eu também estava no carnaval. $\mathrm{O}$ Mel fez uma participação, botaram uns personagens lá. Faziam parte do Mel nas escolas de samba. Ele lutou muito pelos direitos dos homossexuais.

Fizeram isso aí, ficou lindo. Tenho até uma foto dele. Uma ala, lindo. Só de homossexual. Eu queria ver aquela foto de Luciano. Um dia desses, eu estava olhando aqui, "-mas, olha, Luciano mais eu". É muita foto que eu tenho. A lembrança que eu tenho de Luciano é quando ele chegava com aquele jeito comigo, " - a senhora é a rainha das traveca! Das travestis, é você quem manda. Você que faz a nossa parte e eu te considero muito".

Foi dito e feito. Todo mundo no teatro gritando, “- já ganhou, já ganhou". Quando começaram, os jurados escutando aquilo. E eu já que me abri, sem nem saber. A felicidade é que eu sou risonha. Eu nem sabia que ia ganhar. Fiquei feliz, fiquei contente. Eu, em cima do palco, aquelas coisas chiques. Eu, feliz da vida. Quando deu fé, saiu todo mundo para os camarins (Nina Kelly).

\section{Futuros transviados: imaginar}

\section{o impossível}

Do jeito que eu estou vendo, vai melhorar porque agora você vê que o mundo tem muito preconceito, mas está liberal. Tem preconceito, mas está liberal. Pior quando tinha preconceito, que não era liberal. Agora está um troca-troca de nome, de mulher para homem, de homem para mulher, pode trocar agora os nomes. Os documentos podem modificar. Por isso que essas pessoas que são travestis vão ficar mais ainda. Não vão querer ser homem. Não vão querer se produzirem como homem mais. Vão ficar sempre femininas, aí a tendência é melhorar a situação. Você vê que agora querem se casar, serem donas de casa, querem adotar filhos, conseguir trabalho. Que antes era difícil, agora já tem gente trabalhando. Já tem gente botando as pessoas em serviços. (Nina Kelly).

\section{As potências transformativas}

das memórias e das culturas sexo-gênero

dissidentes são vistas como ameaças ao

projeto civilizatório da burguesia

nacional. Lembremos as manifestações

contrárias da extrema-direita à vinda de

Judith Butler ao Brasil em novembro de

2017, acontecimento contemporâneo ao

fechamento da exposição Queer Museu e

a interdição judicial da peça teatral de

Renata de Carvalho, chamada "O

Evangelho Segundo Jesus, Rainha do

Céu”, em que a protagonista é

representada por uma mulher trans:

Nós precisamos desarmar a guerra deles contra nossa imaginação radical para podermos sonhar com mundos que ainda não foram inventados, mesmo que toda semana os tornados reacionários do totalitarismo nos levem a defender coisas que nós já havíamos tomado por garantidas (Mombaça, 2017). 
Nos tempos sombrios de expansão do fascismo, demarcar nossas memórias consiste numa atitude revolucionária. Desde a crise no capitalismo global, nos anos 2007-2008, assistimos ao crescimento do totalitarismo no mundo, agenciado pelas políticas de austeridade, avanço de movimentos antidemocráticos, senso comum ultra conservador, ressurgimento dos grupos de defesa da supremacia branca e dominação masculina cisheterossexual.

João Ricardo W. Dornelles (2017) analisa o cenário desolador para os direitos humanos no contexto autoritário do começo do século XXI. Segundo o autor, no Brasil, as classes médias tradicionais e as elites nacionais gestaram esse momento, inconformadas com a crescente conquista de direitos resultante das políticas sociais durante os governos Lula e Dilma Rousseff, culminando no golpe jurídicoparlamentar de 2016. Entramos numa era de reconcentração do capital, um novo ciclo de acumulação estruturado nas velhas formas de opressão e com novas faces: fundamentalismo neopentecostal, "bolsonarismo" e meritocracia neoliberal.

Lendo o golpe sob uma perspectiva de gênero, Marcia Tiburi enxerga o desmantelamento das feições do Estado de Direito após o impeachment de Dilma Rousseff, presidenta eleita legitimamente. Os herdeiros das velhas elites masculinas cis-heterossexuais, bisnetos dos coronéis do século XIX, decretaram um estado de exceção, operando sua máquina misógina para destruir o processo histórico de construção da democracia brasileira:

Com a saída da presidenta, a misoginia torna-se razão de estado. É o todo da política de governo. Em termos práticos, isso quer dizer o fim do Ministério das mulheres, da igualdade racial, da cultura, da comunicação, do que mais tiver relação com uma política capaz de reconhecer pautas relacionadas a direitos fundamentais. Uma política capaz de reconhecer a importância da participação popular. Uma política capaz de representar os cidadãos. É o fim da democracia representativa. Autorização coletiva para o machismo em todos os níveis, o racismo, os preconceitos de gênero, em uma palavra é o fascismo como negação do outro o que entra em cena com o fim da representação. (Tiburi, 2018: 114).

\section{Para Guy Hocquenghem} (2009), os movimentos sociais e a cultura de resistência sexo-gênero dissidente confrontam diretamente $\mathrm{o}$ projeto civilizatório das ideologias 
fascistas de heteronormalização do corpo burguês, desafiando as tecnologias de sublimação da sexualidade desviante ordenadas pelos valores da família e do Estado falocêntricos. Preciado (2014) complementa que serão as resistências lésbicas, bichas, travestis, trans e demais expressões dissidentes a romper mais radicalmente com os valores conservadores do totalitarismo, acionando $\quad \mathrm{o}$ terrorismo cultural enquanto máquina de guerra.

"No que se refere ao direito à memória, atualmente a comunidade LGBT tem um único direito, o de não ter nenhum", denunciam Jean Baptista e Tony Boita (2017), em estudos sobre nosso lugar nos espaços de memória. Que lugar ocupamos na imagem congelada da família branca patriarcal brasileira? A cultura sexo-gênero dissidente está na borda do patrimônio histórico nacional, de forma que a produção dessas memórias implica na defesa de um patrimônio cultural, na resistência ao silenciamento fascista e na elaboração de narrativas para educação sobre a diversidade de gênero e sexual.

Tratando as aproximações teóricas entre os conceitos de memória e identidade, Carmelo Distante (1988) comenta que serão as reminiscências sobre os modos de ser, viver, falar de um grupo social que demarcará a consciência inconfundível de sua identidade sócio-cultural:

\footnotetext{
Retomando a discussão sobre patrimônio mnemônico-cultural que constitui o capital no qual se baseia a identidade de um povo, de uma comunidade, tribo e pessoa, podemos dizer que ele nada mais é que a herança histórico-biológica e histórico-cultural que dá os sinais característicos ao vulto de uma civilização. (DISTANTE, 1988: 82).
}

A memória coletiva das comunidades sexo-gênero dissidentes tem sido silenciada no Brasil, exterminada na materialidade das violências letais motivadas por ódio. A memória oficial soterra nossas lembranças, nos faz perder os rumos da história, produzindo memórias subterrâneas (Pollak, 1989). O papel de Nina Kelly na construção do patrimônio mnemônico da comunidade sexo-gênero dissidente paraibana encorpa nosso ingresso no projeto de civilização, na luta por direitos movida pelo reconhecimento da própria identidade.

Projetando-se no futuro brasileiro, Nina imagina o intempestivo, uma progressiva travestilização da sociedade, certamente agenciada pelas políticas de inclusão social fomentadas 
nos governos populares. A transgressão do regime de visibilidade para a enunciação de um protagonismo trans nas histórias gloriosas da nação. Sonhar não custa, apesar de reconhecer que "o dinheiro está lá embaixo", expressando os impactos da crise do capital que primeiro atinge as(os) mais pobres.

Nós, dos países vítimas do colonialismo, não ousamos falar somente em mecanismos biomédicos, farmacológicos para a produção do gênero e da sexualidade. A inscrição dos códigos de gênero e sexuais nos corpos negros e indígenas trabalhadores é realizada no campo de batalha da luta pela sobrevivência. A violentação do corpo racializado deixa as marcas do gênero. Por isso Achille Mbembe (2015) desloca a noção foucaultiana de biopolítica para necropolítica em nossos territórios coloniais. Aqui, a soberania define as vidas que importam das que não importam:

Ouvir é, nesse sentido, o ato de autorização em direção à/ao falante. Alguém pode falar (somente) quando sua voz é ouvida. Nesta dialética, aqueles(as) que são ouvidos(as) são também aqueles(as) que "pertencem". E aqueles(as) que não são ouvidos(as), tornam-se aqueles(as) que "não pertencem". A máscara re-cria este projeto de silenciamento, ela controla a
55

possibilidade de que colonizados(as) possam um dia ser ouvidos(as) e, consequentemente, possam pertencer. (Kilomba, 2010:178).

Rosa Maria Godoy Silveira (2016) analisa que a presente fascistização da sociedade brasileira emerge, entre outros fatores históricos, da organização social baseada no padrão familiar patriarcal, marcado pela etnia branca e orientação heterossexual. Em tempos de aumento da barbárie e intolerância, o enfrentamento ao fascismo social passa pela revisitação das concepções de democracia e educação em direitos humanos, privilegiando abordagens que valorizem as diferenças (Dornelles, 2017).

Entre violações e guardins, Nina nos partilhou seus arquivos de dor e alegria, num trabalho contrário às políticas de silêncio que marcam o corpo necropolítico da travesti, num país em que a banalidade do mal conta sua existência já está enraizada nas repetidas estatísticas (Vilela, 2000). Em busca do sentido antropológico dos direitos humanos, Joan-Charles Mèlich escreve sobre a Memória de Auschwitz (2000), atentando-nos para os processos de desconstrução da subjetividade pela violência do holocausto e o nosso 
compromisso, desde então, em evitar o esquecimento de experiências limítrofes, postulando uma ética da identidade pautada na recordação.

Em análise sobre os desafios para a educação em direitos humanos na América Latina, Ana Maria Rodino (2016) pontua que um dos principais desafios das políticas públicas consiste na distância das temáticas abordadas frente às realidades das(os) educandas(os), destacando a escassa referência de materiais locais sobre diversidade sexual e identidades de gênero.

Ao longo de nossa história, a luta dos movimentos sociais pelos direitos da população LGBT tem inventado espaços de pertencimento e participação na sociedade (Gomes, 2016). Na Paraíba, o grupo "Nós Também", considerado o primeiro criado no estado para defesa dos direitos da diversidade, em 1981, atuava por meio de intervenções artísticas, num exercício da dimensão cultural da cidadania. Para além das políticas de reconhecimento, recontar nossas memórias consiste numa ação combativa aos aparelhos fascistas de significação e seus discursos que ditam o extermínio de nossos corpos.

\section{6}

Quanto aos elementos para a construção da personagem Nina Kelly, jamais poderemos resumi-la, localizá-la em uma superfície rasa. Senão, seu corpo ocupa um lugar em trânsito, circular, redondo, contraditório, como a vida real no Brasil. A função narrativa das personagens que emergem do texto variam entre as intenções do discurso e a referência objetiva a seres autônomos, que de fato desempenharam papéis na trajetória da entrevistada (Cândido et al., 1998). A substância mista das memórias estreita a distância entre pessoas e personagens.

\section{Considerações Finais}

Da família biológica, filha de Geralda Piojota, de Serraria, Nina foi a primogênita e não tem notícias sobre pai e irmãos biológicos. Ela tem um irmão adotivo que mora no Rio de Janeiro, o membro da família com grau de parentesco mais próximo que mantém contato. Quanto aos pais adotivos, Maria Rodrigues era dona de casa e parteira, Zé Rodrigues era trabalhador rural. Zé Rodrigues morreu, com cerca de 50 anos, em decorrência do consumo abusivo de álcool e Maria, de óbito natural decorrência da idade avançada. No 
registro civil de nascimento, designaram-lhe o sexo masculino, entretanto, Nina, desde criança, identifica-se com a feminilidade.

A família era católica e foi batizada. Da casa da família adotiva em Mari, por volta dos 10 anos, Nina foi morar na casa do Capitão Eliezer em João Pessoa, responsável pelo restante de sua criação, como se refere em seu discurso. Remetendo-se ao passado na escola como um lugar de exclusão e violência, ela não completou os estudos. $\mathrm{Na}$ casa do Capitão Eliezer, onde recebeu o nome social que carrega até a atualidade, também não frequentou a escola pelos mesmos motivos. Com Genival, Nina morou dez anos, sendo quinze de casamento. Depois de trabalhar muito tempo no serviço doméstico, tornou-se proprietária de sua própria loja de roupas e eletrodomésticos. Cardivan de Oliveira, radialista, chamou Nina pela primeira vez para desfilar numa escola de samba, desde então conta com trinta anos de avenida.

Nina Kelly, habitando as trincheiras culturais do movimento pela libertação sexual na Paraíba através da arte transformista, esteve lado a lado com os militantes engajados na articulação política institucional, dando passos largos para a formação e permanência da comunidade sexogênero dissidente local. Seu corpo visível para além do estigma tem ocupado as avenidas paraibanas, demarcando um território-travesti no espaço urbano cotidianamente tornado cenário de violência. A performance mitológica do carnaval nutre sua alma transformista para fazer existir uma subjetividade próspera, digna e louvável.

Corpos que expressam gêneros não inteligíveis, isto é, que não guardam continuidade entre sexo, gênero e sexualidade, como homens trans, intersexos, travestis, lésbicas, bichas, bissexuais, têm sido colocados historicamente fora do campo da subjetividade jurídica, justamente devido aos processos de abjeção, que lhes negando a humanidade à medida que os enuncia como estranhos, impedem seu reconhecimento à condição de pessoa.

O trabalho de refazenda da memória das dissidências sexuais e de gênero caminha pelo compartilhamento da fala. De minha posição jovem, jamais poderia enunciar tal discurso. Coloqueime como ponte, meu corpo, meus ouvidos, meu coração pronto a escutar as 
histórias narradas pela protagonista da pesquisa e reelaboradas por mim na etapa de transcrição.

Cruzando nossas memórias, desafiando o confinamento dos territórios na sociedade capitalista contemporânea, eu me postei à escuta. Ouvir é o contrário de silenciar. Não sejamos ingênuos, contudo. Foucault já dizia, ainda mais sobre os dispositivos de sexualidade, que o poder também faz dizer, enunciar a si mesmo, obrigando sujeitos a fornecerem uma imagem susceptível ao controle. Aqui, no entanto, estamos agindo pela dilatação das subjetividades históricas na construção de direitos humanos no Brasil.

O conceito de identidade de gênero enunciado pela interlocutora provoca reflexões sobre o não-lugar de mulher ocupado pelas travestis e transexuais femininas na luta por políticas públicas para o seu segmento. A emergência de uma "cara de mulher" e um "nome de homem", a contradição localizada nos órgãos reprodutivos para corpos intersex, a divisão racial e sexual do trabalho imposta a essa população levantam um debate que atinge a problemática da cidadania.

As personagens construídas pela narrativa referem-se às pessoas guardadas na memória ou, de tão deslumbrantes, resultam de suas intenções no discurso? Isto e aquilo! É melhor acreditar na ambivalência do que perder-se no simulacro do verdadeiro. A lição de seus diálogos, gestos, corporalidades e temáticas grafa $o$ estágio movediço em que o real se transfigura no fictício. Ao mergulharmos no oceano das reminiscências trans, enxergamos que o mundo que lutamos para ser verdadeiro está o tempo todo sendo acusado de falsidade, não restando outra atitude perante a vida a não ser estabelecer nossa utopia.

A incorporação do gênero acontece na máquina de costura, no cimento e no tijolo que edifica a casa própria. Mais que um domicílio, um reino de realização de suas fantasias, pagas pelo preço da solidão. Conectar-se às dores do Outro constitui a tarefa essencial dos direitos humanos, em suas dimensões práticas e teóricas. Os momentos de campo mais enriquecedores foram aqueles em que me senti sozinho, distante da família pelas cobranças do capital em acessar a pós-graduação e pelo afastamento homofóbico, e fui até a residência de Nina para uma conversa. 
Cientes de nossas diferenças, nós redescobríamos na dissidência sexual/de gênero um lugar comum. Este local, cheio de abjeção e desumanidade, que tentei materializar nas palavras que compuseram este texto. O método das memórias autobiográficas institui na área interdisciplinar dos direitos humanos um corte contrário à tendência universalizante do humanismo que, na modernidade eurocêntrica assassina, ainda fundamenta os direitos autoevidentes.

As singularidades históricas das vivências pessoais têm o poder de transformar o não-lugar social em habitação resistente, selada pela identidade das lembranças. Eis que brota a sensação de que sempre estivemos por aqui, que a ausência total de direito legislado em matéria de diversidade sexual e de gênero em nível federal não sedimenta um povo vencido, mas demarca um terreno a ser ocupado pelo vigor cultural que nos confere a unidade necessária a esse movimento. Viva a arte transformista! Viva os muitos carnavais de Nina Kelly!

\section{Referências bibliográficas}

59

Baptista, Jean; Boita, Tony (2017). "Memória e esquecimento LGBT nos museus, patrimônios e espaços de memória no Brasil",Revista do centro de pesquisa e formação SESC SP, 5,108119.

Bento, Berenice (2008). O que é transexualidade. São Paulo: Brasiliense.

Bortolozzi, Remon Matheus (2015). “A arte transformista brasileira: rotas para uma genealogia decolonial", Quaderns de Psicologia, 17(3), 123-134. Consultado a 02.07.2019, em https://doi.org/10.5565/rev/qpsicologia. $\underline{1274}$

Burke, Peter (2017). Testemunha ocular: o uso de imagens como evidência histórica. Tradução de Vera Maria Xavier dos Santos. São Paulo: Editora UNESP.

Butler, Judith (2016). Problemas de gênero: feminismo e subversão da identidade. Tradução de Renato Aguiar. Rio de Janeiro: Civilização Brasileira.

Candidoet al. (1998). A personagem de ficção. São Paulo: Editora Perspectiva. 
Distante, Carmelo (1988). "Memória e identidade", Revista Tempo Brasileiro, 1(1), 77-86.

Kilomba, Grada (2010). Plantation Memories: Episodes of Everyday Racism. Tradução de Jéssica Oliveira de Dornelles, João Ricardo (2017).“Direitos humanos em tempos sombrios: barbárie, autoritarismo e fascismo do século XXI",Revista Interdisciplinar de Direitos Humanos, 5(2), 153-168.

Gomes, José Cleudo (2016). Direitos humanos, educação e cidadania LGBT: uma análise das ações do programa Brasil sem Homofobia em João PessoaPB. Dissertação (Mestrado em Educação). Programa de Pós-Graduação em Educação, Universidade Federal da Paraíba. João Pessoa.

Mbembe,

Achille (2016). "Necropolítica", Arte \& Ensaios, Halbwachs, Maurice (1990). A memória coletiva. Tradução de Lauren León Schaffter. São Paulo: Vértice.

Hocquenghem, Guy (2009). El deseo homossexual. Prólogo de René Schérer. Espanha: Mulusin.

Tradução de Renata Santini, 32, 122151.

Meihy, José Carlos Sebe Bom (1996). Manual de história oral. São Paulo: Loyola.

Mèlich, Joan-Carles (2000). “A memória Khède, Sônia Salomão (1982). de Auschwitz", in: Carvalho, Adalberto "Memorialismo e identidade", O eixo e a Dias de (Org.). A educação e os limites roda: memorialismo e autobiografia, 6 , dos direitos humanos: ensaios de 181-195. 


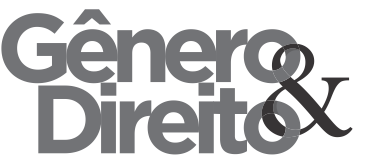

Periódico do Núcleo de Estudos e Pesquisas sobre Gênero e Direito

Centro de Ciências Jurídicas - Universidade Federal da Paraíba

V. 8 - $\mathrm{N}^{\circ} 03$ - Ano 2019

ISSN | 2179-7137 | http://periodicos.ufpb.br/ojs2/index.php/ged/index filosofia da educação. Porto: Editora Porto, 47-59.

Mombaça, Jota (2016). "Rastros de uma Submetodologia Indisciplinada", Revista Concinnitas, 1(28), 341-354.

Mott et al. (2017). Grupo Gay da Bahia - GGB. Mortes violentas de LGBT no Brasil. Relatório 2017. Consultado a 25.01.2019, em https://homofobiamata.files.wordpress.co $\underline{\mathrm{m} / 2017 / 12 / \text { relatorio-2081.pdf }}$

Pollak, Michael (1989). "Memória, esquecimento, silêncio",Estudos históricos, 2(3), 3-15.

Preciado, Paul (2014). Manifesto contrassexual. Tradução de Maria Paula Gurgel Ribeiro. São Paulo: N-1 Edições.

Queiroz, Jandira. Anistia Internacional.“29 de janeiro: um dia nacional de luta pela dignidade da pessoa trans".Página consultada a 14.06.2017, em https://anistia.org.br/29-de-janeiro$\underline{\text { um-dia-nacional-de-luta-pela-dignidade- }}$ para-pessoas-trans/

Rodino, Ana Maria et al. (2016). Cultura e Educação em direitos humanos na
61

América Latina. João Pessoa: Editora da UFPB.

Silva, Helio (1993). Travesti: a invenção do feminino. Rio de Janeiro: RelumeDumará: ISER.

Silveira, Rosa Maria Godoy (2016). A fascistização da sociedade brasileira. In: XXII Encontro Estadual de História, 17, 2016, Guarabira, PB. Anais...Guarabira: ANPUH-PB.

Tiburi, Márcia (2018). “A máquina misógina e o fator Dilma Roussef na política brasileira", in: Rubim; Argolo (Org.) O golpe na perspectiva de gênero. Salvador: Edufba, 107-118.

Trevisan, João Silvério (2000). Devassos no paraíso: a homossexualidade no Brasil, da colônia à atualidade. Rio de Janeiro: Record.

Vainfas, Ronaldo (1989). Trópico dos pecados: moral, sexualidade e inquisição no Brasil. Rio de Janeiro: Nova Fronteira.

Vanoye, Francis (1985). Usos da linguagem: problemas e técnicas na produção oral e escrita. Tradução de 
Clarisse Madureira Saboia. São Paulo:

Martins Fontes.

Vilela, Eugênia (2000). “Os arquivos da dor", in: Carvalho, Adalberto Dias de (Org.). A educação e os limites dos direitos humanos: ensaios de filosofia da educação. Porto: Editora Porto, 126-138 